\title{
Tay Sachs disease in Australia: reduced disease incidence despite stable carrier frequency in Australian Jews
}

\section{Raelia M Lew MB BS(Hons) MMed, Postgraduate Research Student ${ }^{1}$ \\ Anne L Proos MSc, FFSc(RCPA) Scientist ${ }^{2}$ \\ Leslie Burnett MB BS, PhD, FRCPA Pathologist, ${ }^{2}$ and Clinica Professor in Pathology \\ Martin Delatycki \\ MB BS, FRACP PhD Director ${ }^{4,5}$ \\ Agnes Bankier MB BS, FRACP Clinical Geneticist \\ Michael J Fiet $\mathrm{PhD}$ Senior Medical Scientist}

1 Department of Obstetrics, Gynaecolog and Neonatology, University of Sydney,

Sydney, NSW.

2 Pacific Laboratory Medicine Services,

Pathology North NSW Health Pathology, Royal North Shore Hospital, Sydney, NSW.

3 Northern Clinical School, Royal North Shore Hospital, University of Sydney Sydney, NSW.

4 Bruce Lefroy Centre fo Genetic Health Research Murdoch Childrens Research Institute Melbourne, VIC

5 Department of Clinical Genetics, Austin Health, Melbourne, VIC

6 Department of Biochemical Genetics, SA Pathology, Adelaide, SA

rlew2064@

uni.sydney.edu.au

MJA 2012; 197: 652-654 doi: 10.5694/mjal2.11010

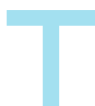

ay Sachs disease (TSD) is an autosomal recessive lysosomal storage disorder caused by mutations of the HEXA gene ${ }^{1}$ (Mendelian Inheritance in Man [MIM] number, ${ }^{*} 606869$; gene map locus, $15 q 23-q 24)^{2}$ that cause hexosaminidase A enzyme deficiency. ${ }^{3}$ It is 100 times more common in Ashkenazi (European) Jews (carrier frequency, 1 in 27) than in general populations (carrier frequency, 1 in 250). ${ }^{4}$ Affected babies appear normal at birth, then experience slow neurological decline and death in infancy (infantile TSD) or early childhood (intermediate TSD). No cure or effective treatment exists.

Preconception genetic screening programs for TSD have been introduced in Jewish communities worldwide to determine individuals' carrier status. ${ }^{5-8}$ Ninety-nine per cent of TSD cases among Jewish people are caused by three known HEXA mutations. ${ }^{9}$ Prospective identification of risk allows individuals and couples to make informed decisions about reproduction.

Based on international best-practice principles, ${ }^{8,10,11}$ Australian genetic screening programs for $\mathrm{TSD}^{12}$ have targeted senior Jewish high school students in Sydney (from 1995 to 2012 through the Australasian Community Genetics Program, Laboratory and Community Genetics Department, Pacific Laboratory Medicine Services [PaLMS], Pathology North) and in Melbourne (from 1998 to 2011 through Victorian Clinical Genetics Services [VCGS]; and in 2012 through Austin Health). Sydney and Melbourne are home to Australia's two largest Jewish communities, where $50 \%-70 \%$ of Jewish high school students attend schools that access screening (Eckstein G. Demography of the Sydney Jewish community: an overview of information from the 2006 Census. Unpublished report commissioned by the Jewish Community Appeal (JCA); copies available on

\begin{abstract}
Abstrac
Objectives: To evaluate the outcomes of preconception screening of Jewish Australians for Tay Sachs disease (TSD) carrier status on Jewish TSD-affected births.

Design, participants and setting: Epidemiological observational study involving a complete retrospective audit of infantile and intermediate TSD cases diagnosed in Sydney and Melbourne between 1 January 1995 and 31 December 2011 (Royal Children's Hospital Melbourne; Pacific Laboratory Medicine Services, Pathology North, NSW Health Pathology, Sydney; Victorian Clinical Genetics Services, Melbourne; and SA Pathology, Adelaide), and carrier frequency among Jewish high school students attending schools participating in TSD screening programs over the same period.
\end{abstract}

Main outcome measures: Jewish TSD carrier frequency; and expected versus observed Jewish TSD-affected births.

Results: The 2006 Census indicated that most of the total 88826 Jewish Australians live in Melbourne (46\%) and Sydney (40\%). The 7756 Jewish high school students screened for TSD in Sydney and Melbourne during the study period had a carrier frequency of one in 31 (3.26\%; 95\% Cl, 2.89\%-3.68\%). The estimated expected number of TSD-affected births in Melbourne and Sydney in 1995-2011 was 4.1 for Jewish births and 7.4 for other births (a ratio of Jewish to non-Jewish births of 1:2). The actual number was 12 (four in Sydney and eight in Melbourne), of which two were Jewish (a ratio of Jewish to non-Jewish births of 1:5). This finding of fewer than expected Jewish TSD cases coincided with a period during which screening programs were operating. There have been no Jewish TSD-affected children born to parents who were screened previously.

Conclusion: Community education, appreciation of autosomal recessive inheritance and genetic carrier screening before pregnancy are the likely factors in our finding of fewer than expected Jewish babies with TSD. Ongoing outcome monitoring must continue.

request from http://www.jca.org.au). The design of the Sydney program, on which the Melbourne program is based, has previously been described. Jewish-community-funded screening is free to students and uptake is high $(99.6 \%) .{ }^{13}$ Screening programs offer testing for additional conditions relevant to the target community, including Fanconi anaemia, familial dysautonomia, Canavan disease, Bloom syndrome, glycogen storage disease type 1a, mucolipidosis type IV, Niemann-Pick disease type $\mathrm{A}$ and cystic fibrosis.

An important measure of the success of a genetic screening program is the reduction of target disease incidence over time. Other measures of success include access to and uptake of screening in the target population. ${ }^{14}$ Here, we report the outcomes of Jewish screening programs for TSD on the incidence of TSD-affected births in Sydney and Melbourne from 1995 to 2011, inclusive.

\section{Methods}

We retrospectively audited all TSD cases diagnosed in Sydney and Melbourne from 1995 through 2011. All samples were processed by one or more of three Australian laboratories (PaLMS, Pathology North, NSW Health Pathology, Sydney; VCGS, Melbourne; and SA Pathology, Adelaide). Laboratory records from these centres pertaining to each case were reviewed. Records of cascade screening (ie, systematic screening of relatives of affected infants) were identified. We audited all laboratory testing for TSD case diagnosis and carrier screening during the study period. This included diagnosis of TSD cases, cascade screening and screening program referrals. Between $50 \%$ and $70 \%$ of Jewish high school students attend Jewish high schools that participate in TSD screening programs. Within TSD screening programs, there is $99 \%$ 
1 Summary of results from Tay Sachs disease (TSD) screening programs in Melbourne and Sydney, 1995-2011

\begin{tabular}{lcccc}
$\begin{array}{l}\text { TSD screening } \\
\text { program }\end{array}$ & $\begin{array}{c}\text { Total students } \\
\text { screened }\end{array}$ & Carriers & Carrier frequency & $95 \% \mathrm{Cl}$ \\
\hline Melbourne & 4097 & 129 & 1 in $32(3.15 \%)$ & $2.66 \%-3.73 \%$ \\
Sydney & 3659 & 124 & 1 in $30(3.39 \%)$ & $2.85 \%-4.03 \%$ \\
Total & 7756 & 253 & 1 in $31(3.26 \%)$ & $2.89 \%-3.68 \%$
\end{tabular}

2 Summary of Australian Bureau of Statistics births data for Sydney, New South Wales, Melbourne and Victoria, 1995-2010

\begin{tabular}{lcccc} 
Year & Sydney & $\begin{array}{c}\text { New South } \\
\text { Wales }\end{array}$ & Melbourne & Victoria \\
\hline $1995-1999$ & Unpublished & 433833 & Unpublished & 303833 \\
$2000-2004$ & 285037 & 430151 & 224458 & 302750 \\
$2005-2009$ & 303045 & 450887 & 257095 & 340931 \\
2010 & 65106 & 95918 & 54023 & 70568 \\
2011 & Unpublished & Unpublished & Unpublished & Unpublished \\
Estimated births 1995-2011 & 1009470 & 1499000 & 827700 & 1081700
\end{tabular}

3 Expected and observed Tay Sachs disease-affected births in Sydney and Melbourne, 1995-2011

\begin{tabular}{|c|c|c|c|c|}
\hline & Jewish & Non-Jewish & Total & $\begin{array}{l}\text { Overall ratio of Jewish } \\
\text { to non-Jewish } \\
\text { TSD-affected births }\end{array}$ \\
\hline Expected births & 4.1 & 7.4 & 11.5 & $1: 2$ \\
\hline Observed births & 2 & 10 & 12 & 1:5 \\
\hline $\begin{array}{l}\text { Rate ratio } \\
(95 \% \mathrm{Cl})\end{array}$ & $\begin{array}{c}0.49 \\
(0.06-1.76)\end{array}$ & $\begin{array}{c}1.35 \\
(0.65-2.49)\end{array}$ & & \\
\hline
\end{tabular}

uptake among students offered screening.

Parents of a child with TSD are routinely asked about Jewish heritage, and this information was obtained from laboratory records, medical records and clinical genetics files. Data from testing laboratories and medical records were cross-referenced to eliminate duplication of cases.

We identified all TSD cases diagnosed and obtained the medical and laboratory records for audit. For all TSD cases identified, parental TSD carrier results were on record. We cross-referenced case and cascade screening results with screening program data. Although our audit of laboratory results identified family members of TSD-affected Jewish children who chose to undertake cascade screening and were found to be TSD carriers, no further analysis was performed on the results of extended cascade screening.

\section{Statistical analysis}

We obtained summary statistics for births registered in Sydney and Melbourne in 1995-2010. ${ }^{15-17}$ Births for 2011 (Australian Bureau of Statistics
[ABS] unpublished data) were estimated based on consecutive data for the previous 15 years. ${ }^{15-17}$ Jewish births for 1995-2010 were proportionally estimated from the 2006 Australian census report, 18,19 and we used the number of $0-4$-year-olds identified as Jewish as a proxy measure for births during this 5-year census period.

De-identified data relating to all students screened for TSD in Sydney 2011 were used to calculate TSD carrier frequency among Jewish students. This was used to model expected TSD-affected births among Jewish Australians. Carrier frequency for TSD in the general Australian population has not been measured. We used the World Health Organization estimate for TSD carrier frequencies in mixed populations ( 1 in 250 or $0.4 \%)^{20}$ to model expected TSD-affected births among non-Jewish Australians.

The predicted numbers of infants born with TSD in Jewish and nonJewish Australians were calculated using the Hardy-Weinberg equation. ${ }^{21}$ ducted using SPSS version 15.0 (IBM SPSS Statistics). in 1995-2011 and Melbourne in 1998-

All statistical analyses were con-

\section{Ethics approval}

Ethics approval was obtained from the Northern Sydney Local Health District Human Research Ethics Committee (HREC) and the Royal Children's Hospital Melbourne HREC.

\section{Results}

In the 2006 census, 88826 of a total 19855288 Australians (0.45\%) identified themselves as Jewish; $46 \%$ of Jewish Australians lived in Melbourne and $40 \%$ in Sydney.

Box 1 shows that the 7756 Jewish high school students screened had a TSD carrier rate of one in 31 (3.26\%); rates were similar in Sydney (3.39\%) and Melbourne (3.15\%).

Box 2 shows ABS births data for Melbourne and Sydney in 1995 through 2011. ${ }^{15-17}$

The 2006 Australian census recorded 4394 Jewish children aged $0-4$ years in Melbourne and Sydney. ${ }^{18}$ The census-based estimate of Jewish births in Melbourne and Sydney in 1995-2011 was 14 940. Box 3 shows numbers of observed and predicted TSD-affected babies born in Sydney and Melbourne in 1995-2011; a total of 12 babies with TSD were born in this period - four in Sydney and eight in Melbourne - of whom two were Jewish.

The observed ratio of Jewish to non-Jewish TSD-affected births was 1:5 compared with the expected ratio of 1:2. No Jewish TSD carrier identified through screening has had a TSD-affected child.

Our audit showed that no parents of TSD-affected Jewish children had participated in screening, and no screening program participants were parents of TSD-affected children.

\section{Discussion}

Twenty years after the introduction of TSD carrier testing in Australia, ${ }^{13}$ there have been fewer than expected Jewish TSD-affected births (Box 3). Further, no genetic carrier identified through screening has had a TSD-affected child. As many of these individuals, now aged $16-38$ years, have not commenced and/or completed their families, the full impact of the screening program is yet to be realised. 
During the study period, most extended families of TSD-affected infants underwent cascade genetic screening, and no parents of an infant with TSD had further TSD-affected children. This is a strong demonstration of the effectiveness of community genetic screening for TSD, supported by appropriate laboratory testing infrastructure.

Current Jewish Australian screening program carrier frequencies are comparable to international Jewish carrier frequencies from 1970 to the present. $^{5}$ TSD predominantly affects those of Ashkenazi Jewish ancestry. Of 4105 Australian Jewish high school students screened for TSD in 1995$2007,78 \%$ of participants and $95 \%$ of carriers were Ashkenazi. ${ }^{22}$ TSD carrier frequencies were 1 in 25 for Ashkenazi Jews and 1 in 97 for those of mixed and non-Ashkenazi Jewish heritage. ${ }^{22}$ No distinction is made in census data between Ashkenazi and other Jewish Australians, so subpopulation analysis was not performed.

The ABS and Jewish community organisations estimate that Jewish Australians underreport their religion in the census, and usually apply a correction factor of $20 \%$ (Eckstein G. Unpublished report; copies available on request from http://www. jca.org.au) We did not apply any correction factor to estimates of Jewish births or expected numbers of Jewish TSD cases.

Our study has limitations relating to the rarity of TSD, the low disease frequency and the small size of the Australian Jewish population. These factors prevented the reduction in observed Jewish TSD cases reaching statistical significance in our study. To demonstrate a significant reduction in cases, it would take 70 years to observe around 12 Jewish TSD cases, using the Poisson model. ${ }^{23}$

TSD testing is now less invasive, ${ }^{24}$ and the cost of laboratory testing has fallen over the 16-year period described in this study. Outreach screening strategies to extend the benefits of TSD preconception screening to a wider target population should be considered.

Overall, we found that since TSD screening commenced in Australia, the number of observed TSD cases in Jewish Australians has halved compared with predictions, while carrier frequency remains high (1 in 31). Preconception carrier screening, supported by community education and the appreciation of autosomal recessive inheritance are the likely key factors explaining the fewer than expected Jewish babies born with TSD.

Acknowledgements: We thank Gary Eckstein and the Jewish Community Appeal for access to commissioned Sydney Jewish community demographic reports. We thank Georgina Luscombe for assistance with statistics and Robert Markham, Raelia Lew's PhD co-supervisor (both from the University of Sydney). We acknowledge the generous support of the Wolper Jewish Hospital, Sydney, and the Pratt Foundation, Melbourne, for funding genetic testing in high school students.

Competing interests: No relevant disclosures.

Received 25 Jun 2012, accepted 15 Oct 2012.

1 Triggs-Raine B, Mahuran DJ, Gravel RA. Naturally occurring mutations in GM2 gangliosidosis: a compendium. Adv Genet 2001; 44: 199-224.

2 Nakai H, Byers MG, Nowak NJ, Shows TB. Assignment of beta-hexosaminidase A alpha-subunit to human chromosomal region 15q23-q24. Cytogenet Cell Genet 1991; 56: 164.

3 Okada S, O'Brien JS. Tay-Sachs disease: generalized absence of a beta-D-Nacetylhexosaminidase component. Science 1969; 165: 698-700.

4 Myerowitz R, Lawson D, Mizukami H, et al. Molecular pathophysiology in Tay-Sachs and Sandhoff diseases as revealed by gene expression profiling. Hum Molec Genet 2002; 11: 1343-1350.

5 Kaback MM, Lim-Steele J, Dabholkar D, et al. Tay-Sachs disease - carrier screening, prenatal diagnosis, and the molecular era. An international perspective, 1970 to 1993. JAMA 1993; 270: 2307-2315.

6 Mitchell JJ, Capua A, Clow C, Scriver CR. Twentyyear outcome analysis of genetic screening programs for Tay-Sachs and beta-thalassemi disease carriers in high schools. Am J Hum Genet 1996; 59: 793-798.

7 Barlow-Stewart K, Burnett L, Proos A, et al. A genetic screening programme for Tay-Sachs disease and cystic fibrosis for Australian Jewish high school students. J Med Genet 2003; 40: e45.

8 Bach G, Zeigler M, Zlotogora J. Prevention of lysosomal storage disorders in Israel. Mol Genet Metab 2007; 90: 353-357.
9 Bach G, Tomczak J, Risch N, Ekstein J. Tay-Sachs screening in the Jewish Ashkenazi population: DNA testing is the preferred procedure. Am J Med Genet 2001; 99: 70-75.

10 Kaback MM. Population-based genetic screening for reproductive counseling: the Tay-Sachs disease model. Eur J Pediatr 2000; 159 Suppl 3: S192-S195.

11 Ekstein J, Katzenstein H. The DorYeshorim story: community-based carrier screening for Tay-Sachs disease. Adv Genet 2001; 44: 297-310.

12 Burnett L, Proos AL, Chesher D, et al. The TaySachs disease prevention program in Australia: Sydney pilot study. Med J Aust 1995; 163: 298-300.

13 Ioannou L, Massie J, Lewis S, et al. Evaluation of a multi-disease carrier screening programme in Ashkenazi Jewish high schools. Clin Genet 2010; 78: 21-31.

14 DelatyckiMB. Population screening for reproductive risk for single gene disorders in Australia: now and the future. Twin Res Hum Genet 2008; 11: 422-430.

15 Australian Bureau of Statistics. Births, Australia 1996. Canberra: ABS, 1997. (ABS Cat.No. 3301.0.) http://www.abs.gov.au/ausstats/abs@.nsf/ ProductsbyReleaseDate/CAICE5C3IFECBDF3CA 25722E001A39FB?OpenDocument (accessed Oct 2012).

16 Australian Bureau of Statistics. Births, Australia, 2010. Canberra: ABS, 2011. (ABS Cat. No. 3301.0.) http://www.abs.gov.au/ausstats/abs@.nsf/mf/ 3301.0 (accessed Oct 2012).

17 Australian Bureau of Statistics. Births, summary of birth statistics 2000-2010. Cat. No. 3301.0. Canberra: ABS, 2011. http://abs.gov.au/ AUSSTATS/abs@.nsf/DetailsPage/3301.02010? OpenDocument (accessed Oct 2012).

18 Australian Bureau of Statistics. 2006 census of population and housing, Australia (Australia), Religious affiliation by sex - time series statistics (1991, 1996, 2001 census years). Canberra: ABS, 2006. (ABS Cat. No. 2068.0.)

19 Australian Bureau of Statistics. 2006 census of population and housing, Australia (Australia) religious affiliation (a) broad groups by sex. Canberra: ABS, 2006. (ABS Cat. No. 2068.0.)

20 World Health Organization. Control of hereditary diseases: report of a WHO scientific group. Technical report series 865. Geneva: WHO, 1996.

21 Hardy GH. Mendelian proportions in a mixed population. Science 1908; 28: 49-50.

22 Lew R, Burnett L, Proos A. Tay-Sachs disease preconception screening in Australia: selfknowledge of being an Ashkenazi Jew predicts carrier state better than does ancestral origin, although there is an increased risk for c. $1421+1 G>C$ mutation in individuals with South African heritage. J Community Genet 2011; 2: 201-209.

23 Przyborowski J, Wilenski H. Homogeneity of results in testing samples from Poisson series: with an application to testing clover seed for dodder. Biometrika 1940; 31: 313-323.

24 Gason AA, Metcalf SA, Delatycki MB, et al. Tay Sachs disease carrier screening in schools: educational alternatives and cheekbrush sampling. Genet Med 2005; 7: 626-632. 